Outcome of delayed follow up in 50 women with abnormal cervical cytology

\begin{tabular}{|c|c|c|c|c|c|c|c|}
\hline \multirow{2}{*}{$\begin{array}{l}\text { Time until } \\
\text { follow up }\end{array}$} & \multirow{2}{*}{$\begin{array}{c}\text { Invasive } \\
\text { carcinoma }\end{array}$} & \multirow{2}{*}{$\begin{array}{l}\text { Microinvasive } \\
\text { carcinoma }\end{array}$} & \multicolumn{2}{|c|}{ Cervical intraepithelial neoplasia } & \multirow{2}{*}{$\begin{array}{c}\text { Total } \\
\text { with } \\
\text { abnormalities }\end{array}$} & \multirow{2}{*}{$\begin{array}{l}\text { Subsequent } \\
\text { normal } \\
\text { cytology }\end{array}$} & \multirow[b]{2}{*}{ Unknown } \\
\hline & & & III & II & & & \\
\hline $\begin{array}{l}\leqslant 3 \text { years } \\
>3 \text { years }\end{array}$ & 1 & 1 & $\begin{array}{l}5 \\
2\end{array}$ & 3 & $\begin{array}{l}5 \\
7\end{array}$ & $\begin{array}{l}15 \\
14\end{array}$ & $\begin{array}{l}2 \\
7\end{array}$ \\
\hline Total & 1 & 1 & 7 & 3 & 12 & 29 & 9 \\
\hline
\end{tabular}

^Including five with persistent minor atypicalities and one with benign warty changes.

grade II, or more severe, with $22 \%$ having grade III or worse and an estimated $5 \%$ having microinvasive or clinical or occult invasive carcinoma. These results confirm our original disquiet that inadequate follow up of patients with even a single, relatively mild abnormality is unacceptably dangerous. This conclusion is highlighted by studies of patients with invasive cervical cancer, which have shown that failure to follow up cytological abnormalities occurred in around $15 \%$ and was a more common problem than that of false negative smears. ${ }^{24}$ Kinlen and Spriggs studied 101 women with atypical smears in the early $1970 \mathrm{~s}^{5}$; they re-evaluated 60 of these after at least two years and found $33(55 \%)$ with persistent or advancing disease: 20 had dysplasia or carcinoma in situ and three microinvasive, three occult invasive, and seven clinically invasive cervical cancer.

We previously identified the reasons for lack of follow up in our patients, and since then the problem has been reduced by better record systems and communications among the laboratory, hospital clinics where smears are taken, and general practitioners. Among the 50 patients described here the failure of initial follow up was due to communication difficulties in 43 instances and to patient refusal in only seven. All these seven patients who initially refused accepted a further invitation after being given information about cytology and the methods by which an abnormal smear could be dealt with.

We conclude that patients who have any degree of abnormality in a smear constitute an extremely high risk group; every effort should be made to reassess these women.

1 Elwood JM, Cotton RE, Johnson J, Jones GM, Curnow J, Beaver MW. Are patients with abnormal cervical smears adequately managed? Br Med f 1984;289:891-4.

2 Ellman $\mathrm{R}$, Chamberlain J. Improving the effectiveness of cervical cancer screening. $\mathcal{Z} R$ Coll Gen Pract 1984;34:537-42.

3 Chisholm DK, Haran D. Cases of invasive cervical cancer in the north west in spite of screening. British foumal of Family Planning 1984;10:3-8.

4 Chamberlain J. Failures of the cervical cytology screening programme. Br Med f 1984;289:853-4. 5 Kinlen LJ, Spriggs AI. Women with positive cervical smears but without surgical intervention. A follow-up study. Lancet 1978;ii:463-5.

(Accepted 10 January 1986)

Department of Pathology, City Hospital, Nottingham NG5 1PB

R E COTTON, MD, FRCPATH, special professor and consultant

Department of Community Medicine and Epidemiology, Medical School, University of Nottingham, Nottingham NG7 2UH

J M ELWOOD, MD, DSC, professor and honorary consultant

GAIL M JONES, BMEDSCI, medical student

Correspondence to: Professor Cotton.

\title{
Radiology for psychiatric patients?
}

An audit of chest $x$ ray examinations, ${ }^{1}$ skull $x$ ray examinations, and computed tomography ${ }^{2}$ suggested overuse of chest and skull $x$ ray examinations. We repeated the audit and report our results.

\section{Patients, methods, and results}

Notes on 1007 consecutive patients aged 16-65 admitted to a district general hospital's psychiatric unit between 1 January 1983 and 31 April 1984 were examined to identify the use of chest and skull radiography and computed previously. One radiograph was abnormal compared with two previously (table). The abnormality, an old fracture known from the history, was the reason for the examination. Management was not altered by the finding.

Computed tomography was conducted on 33 patients (3\%) compared with 13 ( $1 \%$ ) previously; results were abnormal in 12 cases (36\%) compared with four (31\%) before. All patients with abnormal reports had evidence of organic neurological disease in their history or on examination, according to criteria described by Roberts and Lishman. ${ }^{3}$ In no case was management altered because of computed tomographic findings, although in several confirmation of structural abnormality was desired. Thirteen of the 21 patients with normal results on

Use of radiography in patients admitted to psychiatric unit

\begin{tabular}{|c|c|c|c|c|c|c|}
\hline & \multirow[b]{2}{*}{$\begin{array}{c}\text { No of } \\
\text { admissions }\end{array}$} & \multirow[b]{2}{*}{$\begin{array}{l}\text { No (\%) in which } \\
\text { procedure performed }\end{array}$} & \multicolumn{4}{|c|}{ Abnormal $x$ ray films } \\
\hline & & & No & $\begin{array}{c}\% \text { Of } \\
\text { examinations }\end{array}$ & $\begin{array}{c}\% \text { Of } \\
\text { admissions }\end{array}$ & $\begin{array}{l}\text { No in which clinical } \\
\text { findings positive }\end{array}$ \\
\hline \multicolumn{7}{|l|}{ Chest radiography: } \\
\hline Previous study & 746 & $231(31)$ & 21 & 9 & $2 \cdot 8$ & 21 \\
\hline \multirow{2}{*}{\multicolumn{7}{|c|}{$\begin{array}{l}\text { Present suay } \\
\text { Skull radiography: }\end{array}$}} \\
\hline & & & & & & \\
\hline Previous study & 1691 & $111(6 \cdot 6)$ & 2 & 2 & $0 \cdot 1$ & 1 \\
\hline Present study & 1007 & $38(3 \cdot 8)$ & 1 & 2 & 0.1 & 1 \\
\hline \multicolumn{7}{|c|}{ Computed tomography: } \\
\hline Previous study & 1691 & $13(0 \cdot 8)$ & 4 & 31 & 0.2 & 4 \\
\hline Present study & 1007 & $33(3 \cdot 3)$ & $12 \ddagger$ & 36 & $1 \cdot 2$ & 12 \\
\hline
\end{tabular}

*Abnormal findings in history or on clinical examination.

tInfective changes (12 cases), emphysema (six), cardiomegaly (six), fractured ribs (four), suspected active tuberculosis (three), pleural calcification (one), and pleural effusion (one)

†Cortical atrophy (eight cases), cerebral infarction (two), hydrocephalus (one), periventricular lucency (one), and localised attenuation deep in a cerebral hemisphere (one). (A table giving more details is available from AJW.)

tomography of the head (EMI 1010). If a report of a chest or skull $x$ ray film had described significant abnormality the clinical findings in the notes were abstracted. ${ }^{3}$ The notes on all computed tomograms were examined.

Chest radiography was performed on 136 patients $(14 \%)$ compared with 231 (31\%) previously. Results were abnormal in 32 cases $(24 \%)$ compared with $21(9 \%)$ before (table). One report of infective shadowing was unsuspected and necessitated treatment. This and another case of infective changes were judged to have precipitated or perpetuated the episodes of mental illness, hypomania, in each case. No other finding was unsuspected.

Skull radiography was carried out on 38 patients (4\%) compared with $111(7 \%)$ computed tomography had clinical evidence of organic brain disease. Their diagnoses were: affective psychosis (eight cases), organic psychosis (three), and schizophrenia (two). The remaining eight had atypical or prolonged affective psychoses (six cases), schizophrenia (one), and personality disorder (one)

\section{Comment}

Two studies have shown a reduction in the use of radiography. Reductions of $40 \%$ and $27 \%$ in the use of chest radiography in surgical wards of two 
hospitals were attributed to publicity about overuse. ${ }^{4}$ In our hospital use of chest radiography has fallen by $55 \%$ since the first survey. That appropriate use has been sustained or improved is suggested by a small increase in the proportion of patients admitted with an abnormal chest $x$ ray film. The increased proportion of examinations showing significant abnormality from $9 \%$ to $24 \%$ suggests a reduction in routine or screening radiography. The findings suggest that in adult psychiatry chest radiography should be used when there is clinical evidence of cardiothoracic disease or unexplained failure of an episode of mental illness to remit, and screening should be confined to alcoholism. ${ }^{1}$

A reduction of $51 \%$ in the use of skull radiography occurred after guidelines were issued to junior staff assessing head injuries. ${ }^{5}$ In our hospital the use of skull radiography has fallen by $42 \%$ since the first survey. All patients with an abnormality on computed tomography showed normal results on skull radiography. Skull radiography is thus not useful in adult psychiatry.

The use of computed tomography increased from $0.8 \%$ to $3 \cdot 3 \%$ of admissions. The proportion of abnormal results increased from $31 \%$ to $36 \%$, suggesting that clinical judgment is improving. Abnormal radiological findings were confined to patients with clinical evidence of organic brain disease. Prolonged or atypical affective psychoses accounted for most normal scans. The findings suggest that in adult psychiatry computed tomography is of value only when there are symptoms or signs of neurological disease.

1 Hughes J, Barraclough BM. Value of routine chest radiography of psychiatric patients. Br Med $\mathcal{f}$ 1980;281:1461-2.

2 Rastogi SC, Barraclough BM. Skull radiology in patients with psychiatric illness. $\mathrm{Br}$ Med $\mathcal{J}$ 1983;287:1259.

3 Roberts JKA, Lishman WA. The use of the CT scanner in psychiatry. Br $\mathcal{J}$ Psychiatry 1984; 145:152-8.

4 Roberts CJ, Fowkes FGR, Ennis WP, Mitchell M. Possible impact of audit on chest $x$-ray requests from surgical wards. Lancet 1983;ii:446-8.

5 Fowkes FGR, Evans RC, Williams LA, Gehlbach SH, Cooke BRB, Roberts CJ. Implementation of guidelines for skull $\mathrm{x}$-ray in patients with head injuries. Lancet 1984;ii: 795-7.

(Accepted 9 Fanuary 1986)

Department of Psychiatry, Royal South Hants Hospital, Southampton SO9 4PE

ANTHONY J WHITE, MRCPSYCH, registrar in psychiatry

BRIAN BARRACLOUGH, FRACP, senior lecturer in psychiatry

Correspondence to: Dr A J White, Barrow Hospital, Bristol BS19 3SG.

\section{Low serum C4 concentrations and microangiopathy in type I and type II diabetes}

Low $\mathrm{C} 4$ concentrations are thought to occur in about $25 \%$ of type I diabetics and are probably related to an increased frequency of the null alleles for $\mathrm{C} 4 .^{12}$ A recent study suggested that low $\mathrm{C} 4$ concentrations reflect and may predict microvascular disease in type I diabetics. ${ }^{3}$ We studied the relation of serum C4 concentrations to microvascular complications in 123 type I and 140 type II diabetics.

\section{Patients, methods, and results}

We studied all 263 patients who attended the Austin Hospital diabetes clinic between November 1984 and April 1985. The patients were regarded as having type I diabetes if they had persistent ketonuria, weight loss on presentation, and insulin dependency within one month of diagnosis $(n=123)$; all other patients were classified as having type II diabetes $(n=140)$. Serum $C 4$ concentrations were measured by radial immunodiffusion (Kallestad). ${ }^{4}$ Proliferative retinopathy was diagnosed independently by an ophthalmologist. Diabetic nephropathy was defined as proteinuria exceeding $0.3 \mathrm{~g} / 24 \mathrm{~h}$ by a trichloroacetic acid precipitation method (all dipstick results (Albustix) $\geqslant 0.3 \mathrm{~g} / \mathrm{l}$ ). ${ }^{5}$ Statistical comparisons were performed using Student's $t$ test for normally distributed variables, the MannWhitney (W) test for $\mathrm{C} 4$ concentrations, and $\chi^{2}$ analysis for comparing the prevalence of retinopathy and proteinuria on dipstick testing between different groups.

Fourteen type I and 11 type II diabetics had proliferative retinopathy, and 19 and 24 , respectively, had proteinuria on dipstick testing; creatinine clearance was $1.74(0.06) \mathrm{ml} / \mathrm{s}$ in type I and $1.61(0.06) \mathrm{ml} / \mathrm{s}$ in type II diabetics. Type I diabetics had lower $\mathrm{C} 4$ concentrations than type II diabetics (median $20 v 27.5 \mathrm{mg} / 100 \mathrm{ml}$ Mann-Whitney test $p<0.001$ ). There was no significant difference in $C 4$ concentrations between patients with and without microvascular complications in type I or type II diabetics (table). There was no correlation between $\mathrm{C} 4$ concentrations and duration of diabetes, the age of the patient at the time of study, and the age of the patient at diagnosis.

Mean (SEM) serum C4 concentrations in diabetics with and without microvascular complications $(\mathrm{mg} / 100 \mathrm{ml})^{\star}$

\begin{tabular}{lcclccc}
\hline & \multicolumn{2}{c}{ Type I diabetics } & & \multicolumn{2}{c}{ Type II diabetics } \\
\cline { 2 - 3 } \cline { 5 - 6 } \cline { 5 - 6 } & No of patients & $\mathrm{C} 4$ & & No of patients & $\mathrm{C} 4$ \\
\hline Total group & 123 & $22 \cdot 0(0 \cdot 8)$ & & 140 & $28 \cdot 3(0 \cdot 8)$ \\
Yroliferative retinopathy & 21 & $25 \cdot 9(2 \cdot 8)$ & & 11 & $30 \cdot 1(4 \cdot 6)$ \\
Diabetic nephropathy & 21 & $23 \cdot 0(2 \cdot 1)$ & & 32 & $28 \cdot 9(2 \cdot 0)$ \\
$\begin{array}{l}\text { No microvascular } \\
\text { complications }\end{array}$ & 97 & $21 \cdot 2(0 \cdot 8)$ & & 102 & $28 \cdot 2(0 \cdot 9)$ \\
\hline
\end{tabular}

*Normal range based on 50 normal subjects is $16-45 \mathrm{mg} / 100 \mathrm{ml}$ (means $2 \mathrm{SD}$ ). Type I $v$ type II: $\mathrm{p}<0.001$.
The prevalence of microvascular complications in type I diabetics with $\mathrm{C} 4$ concentrations below the normal range $(<16 \mathrm{mg} / 100 \mathrm{ml})$ was compared with that in type I diabetics with $\mathrm{C} 4$ concentrations within the normal range. There was no difference in the prevalence of retinopathy (numbers of patients with nil, background, proliferative retinopathy $19,5,3, v 71,14,11 ; \chi^{2}=0 \cdot 21$, NS), creatinine clearance $(1.74(0.11) v 1.74(0.07) \mathrm{ml} / \mathrm{s} ; \mathrm{p}=0.99)$, or proteinuria on dipstick testing $\left(6 / 27 v 14 / 95 ; \chi^{2}=0 \cdot 86\right.$, NS) between type I diabetics with low $(n=27)$ and normal $C 4$ concentrations $(n=96)$.

\section{Comment}

These results confirm previous reports that about a quarter of type I diabetics have subnormal C4 concentrations. ${ }^{1}$ This was not found in type II diabetics. Type I diabetics with advanced microvascular disease did not show further lowering of $\mathrm{C} 4$ concentrations compared with diabetics without complications. These data are in contrast with findings of a previous study in which type I diabetics with complications had lower $\mathrm{C} 4$ concentrations than type I diabetics without complications. ${ }^{3}$ The difference in results between the two studies is difficult to explain in terms of patient selection, criteria for type I and type II diabetes, definition of microvascular complications, and assay methods. This study suggests that low serum C4 concentrations are a manifestation of type I diabetes, independent of the presence of microvascular disease.

1 Vergani D, Johnston C, Abdullah NB, Barnett AH. Low serum C4 concentrations: an inherited predisposition to insulin dependent diabetes. BrMed f 1983;286:926-8.

O'Neill GJ, Young SY, Dupont B. Two HLA linked loci controlling the 4 th component of human complement. Proc Natl Acad Sci USA 1978;75:5165-9.

3 Barnett AH, Mijovic C, Fletcher J, et al. Low plasma C4 concentrations: association with microangiopathy in insulin dependent diabetes. Br Med f 1984;289:943-5.

4 Mancini G, Carbonara AO, Heremans SF. Immunochemical quantitation of antigens by single radial immunodiffusion. Immunochemistry 1965;2:235-54.

5 Koller A. Total urine protein. In: Kaplan L, Pesce A, eds. Clinical chemistry. Missouri: C V Mosby and Co, 1984:1319-24.

(Accepted 6 fanuary 1986)

Endocrine Units and Departments of Medicine and Immunohaematology,

University of Melbourne, Austin Hospital, Victoria 3084, Australia

MARK E COOPER, MB, BS, endocrine fellow

RICHARD DUFF, MB, BS, resident medical officer

RUSSELL BUCHANAN, MB, FRACP, lecturer in medicine

JEFF MCPHERSON, MSC, senior scientist

GEORGE JERUMS, MD, FRACP, senior endocrinologist

Correspondence and requests for reprints to: Dr Cooper. 